\title{
HUBUNGAN USIA DAN LAMA KERJA DENGAN KELUHAN NYERI PUNGGUNG BAWAH PADA NELAYAN DI KELURAHAN BELAWAN II
}

\author{
Saqila Syalsabila Br Silitonga ${ }^{1}$, Tri Niswati Utami ${ }^{2}$ \\ Fakultas Kesehatan Masyarakat, Universitas Islam Negeri Sumatera Utara \\ saqilas34@gmail.com ${ }^{1}$, triniswatiutami@uinsu.ac.id ${ }^{2}$
}

\begin{abstract}
The life of coastal communities on average has a job as a fisherman. Working as a fisherman also has a high risk of low back pain complaints due to extending working hours during fishing. Activities that are repeated for a long time can cause complaints of low back pain. The purpose of this study was to see the relationship between age and length of work with complaints of low back pain in fishermen in Belawan II Village. This type of research is an analytic observational study with a cross-sectional study design. The number of samples in this study was 70 samples. The results of statistical analysis showed that rejecting Ho, which means that there is a significant relationship between age and complaints of low back pain $(p=0.004)$. In respondents experiencing complaints of low back pain who have a working time of $\geq 8$ hours as many as 29 people $(41.42 \%)$ with a value ( $p$-value $=0.032$ ). The results showed that age and length of work had a relationship with complaints of low back pain.
\end{abstract}

Keywords $\quad$ : Length of Working, Fisherman, Low Back Pain, Age

\begin{abstract}
ABSTRAK
Kehidupan masyarakat pesisir rata-rata memiliki pekerjaan sebagai nelayan. Bekerja sebagai nelayan juga memiliki risiko keluhan low back pain yang tinggi dikarenakan dengan memperpanjang waktu jam kerja pada saat penangkapan ikan. Aktivitas yang berulang-ulang dalam waktu yang lama dapat menyebabkan keluhan low back pain. Tujuan penelitian ini untuk melihat hubungan usia dan lama kerja dengan keluhan nyeri punggung bawah (low back pain) pada nelayan di Kelurahan Belawan II. Jenis penelitian ini merupakan penelitian observasional analitik dengan desain studi cross-sectional. Jumlah sampel pada penelitian ini adalah 70 sampel. Hasil analisis statistik menunjukkan bahwa menolak Ho yang artinya terdapat hubungan yang signifikan antara usia dengan keluhan nyeri punggung bawah (low back pain) $(p=0,004)$. Pada responden mengalami keluhan low back pain yang memiliki waktu kerja $\geq 8$ jam sebanyak 29 orang $(41,42 \%)$ dengan nilai $(p$-value $=0,032)$. Hasil penelitian menunjukkan usia dan lama kerja memiliki hubungan dengan keluhan nyeri punggung bawah (low back pain).
\end{abstract}

Kata Kunci : Lama Kerja, Nelayan, Nyeri Punggung Bawah, Usia

\section{PENDAHULUAN}

Sumber kehidupan masyarakat pesisir tidak lepas dari profesi nelayan, selain nelayan juga terdapat profesi sebagai penyelam. Nelayan adalah suatu kelompok masyarakat yang kehidupannya tergantung langsung pada hasil laut, baik dengan cara melakukan penangkapan ataupun budidaya (PERMEN-KP, 2018).

Salah satu penyakit akibat kerja yang secara umum menjadi masalah kesehatan di dunia dan hampir mempengaruhi seluruh populasi yaitu keluhan musculoskeletal. Keluhan musculoskeletal adalah keluhan yang terjadi di bagian otot, saraf, sendi, tenden yang berkaitan dengan pekerjan (European Agency for Safety and Health at Work, 2019).

Keluhan musculoskeletal yang sering dialami oleh nelayan yaitu nyeri punggung bawah (low back pain). Low back pain adalah suatu kondisi tidak spesifik yang mengakibatkan rasa nyeri dan pegal pada 
punggung bagian bawah. Penyebab nyeri punggung bawah biasanya diakibatkan dari kelainan yang terjadi di jaringan lunak misalnya cedera otot, ligamen, ataupun keletihan otot (Ruhaya, 2018).

Nyeri punggung bawah dapat mengakibatkan penurunan produktivitas manusia yang dapat membuat seseorang sering berobat ke dokter sehingga memberikan dampak buruk bagi sosialekonomi dikarenakan berkurangnya hari kerja (Tanderi, Kusuma, \& Hendrianingtyas, 2017).

World Health Organization (WHO) telah mengidentifikasi low back pain sebagai salah satu dari tiga masalah kesehatan teratas yang menjadi target pengawasan. Menurut WHO, low back pain adalah penyebab utama kecacatan di seluruh dunia dengan prevalensi global $7,2 \%$, mempengaruhi 4 dari 5 orang dalam hidup mereka. Berdasarkan data International Labour Organization (ILO) tahun 2018 menyebutkan bahwa diperkirakan lebih dari 1,8 juta kematian akibat kerja terjadi setiap tahunnya di kawasan Asia dan Pasifik. Bahkan dua pertiga kematian akibat kerja di dunia terjadi di Asia. Kecelakaan atau penyakit akibat kerja di tingkat global, sekitar lebih dari 2,78 juta orang meninggal setiap tahun.

Negara Indonesia mengalami kejadian low back pain sebesar $18 \%$ dan kemungkinan akan terus meningkat dengan seiring bertambahnya usia dan ini sering terjadi di usia dekade tengah dan awal dekade empat yang $85 \%$ penyebabnya non spesifik. Berdasarkan data Badan Pusat Statistik (2018), terdapat $26,74 \%$ penduduk usia 15 tahun keatas yang bekerja mengalami keluhan dan gangguan kesehatan (Kemenkes RI, 2018). Hal ini dikarenakan semakin bertambahnya usia seseorang maka kekuatan otot pun semakin menurun.

Penurunan fisiologis, neurologis, dan kemampuan fisik terjadi sesudah usia 30 sampai 40 tahun dengan irama yang berbeda untuk setiap orang. Menurut penelitian (Sangaji et al., 2020) pada usia
35 tahun keluhan pertama nyeri musculoskeletal mengalami peningkatan. Hal ini juga diperkuat oleh penelitian yang dilakukan oleh (Leni \& Triyono, 2018) bahwa seseorang yang lebih rentan mengalami keluhan musculoskeletal termasuk pada bagian punggung bawah yaitu pekerja yang berusia tua.

Lama kerja adalah lamanya waktu yang dilalui seseorang dalam melakukan suatu kegiatan. Semakin lama seseorang bekerja dalam suatu organisasi, maka semakin lebih baik keterampilan kerja yang dialami orang tersebut. Menurut hasil penelitian yang dilakukan oleh (Waworuntu et al., 2019), lama kerja berhubungan dengan keluhan nyeri punggung ketika seseorang bekerja terlalu lama atau $\geq 8$ jam perhari.

Kegiatan yang dilakukan oleh nelayan ada beberapa tahapan yaitu tahap persiapan, tahap operasi penangkapan, tahap penurunan dan penarikan jaring, dan tahap pengangkutan hasil tangkapan.

Berdasarkan survey awal yang dilakukan peneliti didapatkan data sebanyak 12 nelayan yang mengeluhkan nyeri punggung bawah (low back pain). Dari pengambilan data di Puskesmas Belawan pasien yang mengalami keluhan nyeri punggung bawah (low back pain) berusia sekitar $\geq 30$ tahun sampai 70 tahun.

Keluhan yang sering dirasakan oleh nelayan yaitu sakit dibagian punggung ataupun pinggang, merasa kaku di bagian leher atas, dan sakit pada bahu, ini terjadi setelah melakukan operasi penangkapan ikan. Penangkapan ikan biasanya dilakukan oleh nelayan pada waktu sore hari di jam 15-00-03.00 Wib dan malam hari pada jam 22.00-08.00 Wib. Hasil penangkapan yang maksimal dibutuhkan waktu 10-15 jam.

Kegiatan yang biasanya dapat mempercepat terjadinya kelelahan otot pada nelayan dikarenakan melakukan penurunan dan pengangkatan jaring yang dilakukan sebanyak 8 kali dengan durasi \pm 10 menit per setting. Jika aktivitas yang mengharuskan nelayan melakukan suatu pekerjaan dalam posisi yang dinamis 
misalnya duduk, jongkok, berdiri, mengangkat, berjalan, dan membungkuk secara berulang-ulang dalam waktu yang lama inilah yang menyebabkan nelayan mengalami keluhan nyeri di bagian punggung bawah.

Tujuan dari penelitian ini adalah untuk menganalisis hubungan usia dan lama kerja dengan keluhan low back pain pada nelayan.

\section{METODE}

Jenis penelitiaan ini bersifat observasional analitik dengan desain studi cross-sectional. Penelitian ini dilakukan di daerah pesisir Kelurahan Belawan II pada bulan Januari - September 2021. Variabel dalam penelitian ini adalah usia, lama kerja, dan keluhan nyeri punggung bawah. Populasi dalam penelitian ini adalah seluruh nelayan yang berada di Kelurahan Belawan II yaitu sekitar 229 nelayan. Teknik pengambilan sampel ini dengan menggunakan rumus slovin. Pengambilan data usia dan lama kerja menggunakan kuesioner dan data low back pain menggunakan kuesioner Modified ODI (Oswestry Low Back Pain Disability Questionnaire). Kemudian hasil data tersebut dianalisis menggunakan uji chisquare.

HASIL

Karakteristik Responden Berdasarkan Usia
Tabel 1. Distribusi Frekuensi Responden Berdasarkan Usia pada Nelayan di Kelurahan Belawan II

\begin{tabular}{ccc}
\hline Usia & Frekuensi & Persentase $(\%)$ \\
\hline$\geq 30$ tahun & 66 & 94,3 \\
$<30$ tahun & 4 & 5,7 \\
\hline Total & 70 & 100 \\
\hline
\end{tabular}

Pada tabel diatas didapatkan data responden berdasarkan usia $\geq 30$ tahun sebanyak 66 orang $(94,3 \%)$ dan responden dengan usia $<30$ tahun sebanyak 4 orang $(5,7 \%)$.

\section{Karakteristik Responden Berdasarkan Lama Kerja}

Tabel 2. Distribusi Frekuensi Responden Berdasarkan Lama Kerja pada Nelayan di Kelurahan Belawan II

\begin{tabular}{ccc} 
Lama Kerja & Frekuensi & Persentase \\
\hline$\geq 8$ jam & 50 & 71,4 \\
$<8$ jam & 20 & 28,6 \\
\hline Total & 70 & 100 \\
\hline
\end{tabular}

Berdasarkan tabel 2 diatas didapatkan data responden dengan lama kerja $\geq 8$ jam sebanyak 50 orang $(71,4 \%)$ dan responden dengan lama kerja $<8$ jam sebanyak 20 orang $(28,5 \%)$. Dapat disimpulkan bahwa responden yang memiliki jam kerja $\geq 8$ jam lebih banyak dibandingkan responden dengan jam kerja $<8$ jam.

Tabel 3. Hubungan Antara Usia dan Lama Kerja dengan Keluhan Low Back Pain pada Nelayan di Kelurahan Belawan II

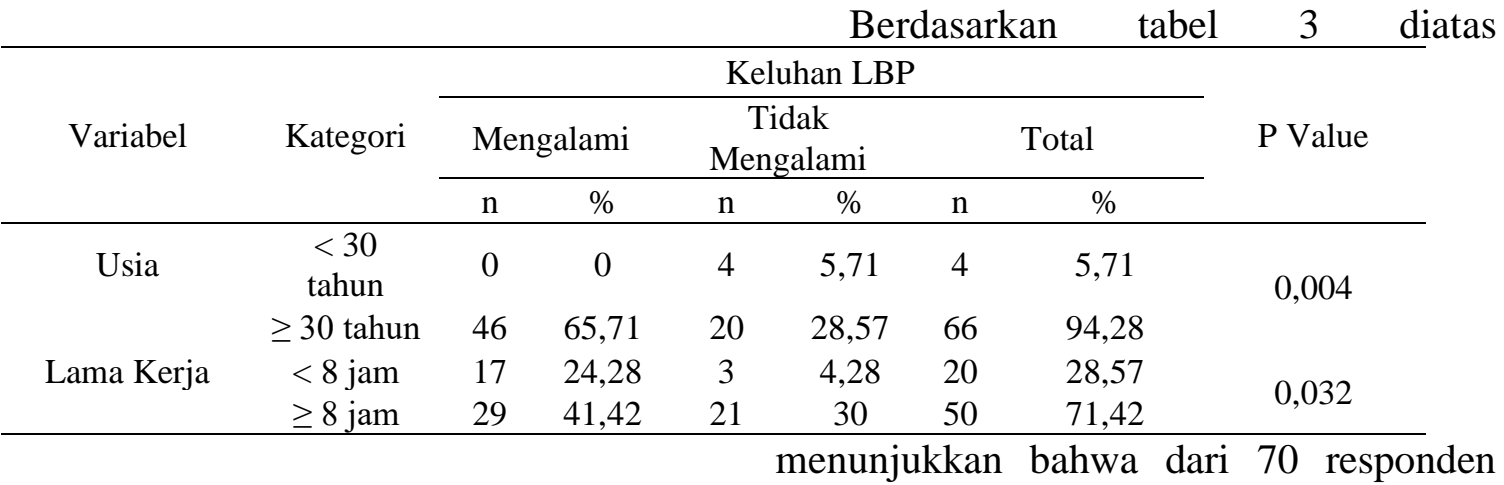


yang mengalami keluhan low back pain pada usia < 30 tahun sebanyak 0 responden $(0 \%)$ dan pada usia $\geq 30$ tahun sebanyak 46 responden ( $65,71 \%$ ). Sedangkan responden yang tidak mengalami low back pain pada usia $<30$ tahun sebanyak 4 responden $(5,71 \%)$. Hasil analisis statistik menunjukkan bahwa menolak Ho yang artinya terdapat hubungan yang signifikan antara usia dengan keluhan nyeri punggung bawah (low back pain) $(p=0,004)$.

Tabel 3 diatas juga menunjukkan bahwa dari 70 responden yang mengalami keluhan low back pain dengan kategori lama kerja $<8$ jam sebanyak 17 responden $(24,28 \%)$ dan kategori lama kerja $\geq 8$ jam sebanyak 29 responden $(41,42 \%)$. Sedangkan responden yang tidak mengalami low back pain dengan kategori lama kerja $<8$ jam sebanyak 3 responden $(4,28 \%)$ dan kategori lama kerja $\geq 8$ jam sebanyak 21 responden (30\%). Pada variabel lama kerja didapatkan hasil analisis statistik yang menunjukkan bahwa menolak Ho yang artinya terdapat hubungan yang signifikan antara lama kerja dengan keluhan nyeri punggung bawah (low back pain) $(p=0,032)$.

\section{PEMBAHASAN}

Nyeri punggung bawah adalah keluhan rasa nyeri yang dirasakan pada bagian punggung bawah yang bersumber dari tulang belakang daerah spinal, otot, saraf, dan struktur lainnya. Umumnya nyeri punggung bawah (low back pain) terjadi di daerah punggung yaitu antara sudut bawah kosta (tulang rusuk) sampai pada bagian lumbosacral (sekitar tulang ekor). Keluhan ini juga merupakan salah satu keluhan yang dapat menurunkan produktivitas kerja (Nurindasari, 2016).

Posisi duduk statis dapat menyebabkan gangguan muskuloskeletal termasuk low back pain, hal ini sering dialami oleh nelayan ketika menangkap ikan yang beratnya membutuhkan tenaga dalam menarik beban ikan menggunakan tumpuan kaki yang kemudian diangkat ke ruang tunggu kapal (Sangaji et al., 2020).

Pengukuran nyeri punggung bawah (low back pain) ini dilakukan dengan menggunakan kuesioner Modified ODI (Oswestry Low Back Pain Disability Questionnaire). Metode ini digunakan untuk mengukur tingkat keluhan nyeri punggung yang dirasakan pada nelayan berdasarkan pertanyaan-pertanyaan tentang aktivitas yang sering dilakukan sehari-hari dalam bekerja.

Hasil yang di dapatkan dari pengukuran menggunakan kuesioner Modified ODI (Oswestry Low Back Pain Disability Questionnaire) yaitu terdapat 46 orang $(65,7 \%)$ mengalami keluhan nyeri punggung bawah (low back pain) dan 23 orang $(32,9 \%)$ tidak mengalami keluhan nyeri punggung bawah (low back pain).

Penelitian ini sejalan dengan penelitian (Waworuntu et al., 2019) bahwa tidak hanya pekerja nelayan tetapi pengendara ojek online sering merasakan keluhan nyeri punggung bawah (low back pain) dan diperoleh hasil dari 100 responden yang mengalami tingkat keluhan sering berjumlah 56 orang (56\%) dan yang mengalami tingkat keluhan jarang berjumlah 44 orang (44\%).

\section{Hubungan Usia dengan Keluhan Nyeri Punggung Bawah (Low Back Pain)}

Degenerasi pada tulang terjadi seiring dengan meningkatnya usia dan dimulai disaat seseorang berusia 30 tahun. Degenerasi yang terjadi seperti kerusakan jaringan, penggantian jaringan, dan pengurangan cairan. Hal ini dapat menyebabkan stabilitas pada tulang dan otot menjadi berkurang. Semakin tinggi risiko dikarenakan semakin tua orang tersebut dan dapat mengalami penurunan elastisitas pada tulang yang menjadi pemicu timbulnya gejala low back pain (Utami, 2017).

Dalam penelitian ini terdapat 2 kategori yaitu usia $\geq 30$ tahun dan usia $<$ 30 tahun. Responden dengan usia $\geq 30$ 
tahun sebanyak 66 orang dan responden dengan usia $<30$ tahun sebanyak 4 orang. Hasil analisis statistik menunjukkan bahwa menolak Ho yang artinya terdapat hubungan yang signifikan antara usia dengan keluhan nyeri punggung bawah (low back pain) $(p=0,004)$.

Menurut asumsi peneliti bahwa usia $\geq$ 30 tahun sangat berisiko menderita keluhan nyeri pada punggung bawah dikarenakan bertambahnya usia seseorang maka kekuatan otot tubuh pun semakin menurun.

Penelitian lain (Saputra, 2020) menunjukkan bahwa ada hubungan antara usia dengan keluhan low back pain dengan nilai $\quad(p=0,020)$. Responden yang mengalami low back pain dikarenakan terlalu lama bekerja dan juga bertambahnya usia pada pekerja yang dapat meningkatkan resiko mengalami pengurangan elastisitas pada tulang dan stabilitas pada otot (Waworuntu et al., 2019).

Penelitian ini bertolak belakang dengan penelitian (Wahab, 2019) tentang faktor-faktor yang berhubungan dengan keluhan nyeri punggung bawah (low back pain) pada nelayan di Desa Batu Karas Kecamatan Cijulang Pangandara didapatkan hasil uji statistik $\mathrm{p}=0,214$ yang artinya bahwa usia tidak berhubungan dengan kejadian nyeri punggung bawah (low back pain).

\section{Hubungan Lama Kerja dengan Keluhan Nyeri Punggung Bawah (Low Back Pain)}

Lama kerja adalah lamanya waktu seseorang dalam melakukan kegiatan. Semakin lama seseorang itu bekerja, maka semakin lebih baik keterampilan kerja yang dialami orang tersebut (Sangaji et al., 2020).

Pada umumnya lamanya seseorang bekerja dalam sehari sekitar 6 - 8 jam. Jika waktu kerja lebih dari jam tersebut akan menimbulkan penurunan produktivitas kerja terkait kondisi kelelahan, kecelakaan kerja dan penyakit akibat kerja. Jam kerja pada penelitian ini sangat berhubungan dengan keluhan low back pain.

Nelayan melakukan aktivitasnya dalam menangkap ikan yaitu di malam hari sampai pagi hari. Pada pemberangkatan sore hari dilakukan pada jam 15.00-03.00 WIB dan waktu pemberangkatan malam hari pada jam 22.00-08.00. Penangkapan ikan ini dibutuhkan waktu paling lama 10-15 jam untuk mendapatkan hasil yang maksimal. Aktivitas gerakan yang dilakukan secara berulang-ulang oleh nelayan saat pengoperasian alat dalam waktu yang lama dapat menyebabkan keluhan low back pain.

Hasil penelitian ini menunjukkan bahwa responden yang mengalami keluhan low back pain memiliki waktu kerja $\geq 8$ jam sebanyak 29 orang $(41,42 \%)$ yang artinya semakin lama waktu kerja yang dialami seseorang maka semakin tinggi resiko keluhan low back pain. Pada variabel lama kerja didapatkan hasil analisis statistik yang menunjukkan bahwa menolak Ho yang artinya terdapat hubungan yang signifikan antara lama kerja dengan keluhan nyeri punggung bawah (low back pain) $(p=0,032)$.

Menurut asumsi peneliti bahwa nelayan yang bekerja $\geq 8$ jam tidak mengalami keluhan low back pain jika usia pekerja < 30 tahun. Hal ini dikarenakan nelayan yang berusia $<30$ tahun masih memiliki kekuatan otot yang masih normal.

Lama kerja berdasarkan penelitian (Betty, 2020) terdapat hubungan yang signifikan antara lama kerja dengan kejadian low back pain dengan $\mathrm{p}$ value sebesar 0,0001 ( $\mathrm{p}<0,05)$. OR (Odds Ratio) 13.929 dengan CI (Confidence Interval) 95\% antara 5.167 sampai 37.548). Hasil penelitian ini menunjukkan bahwa penjahit yang bekerja dengan lama kerja $>8$ jam berisiko 14 kali mengalami kejadian low back pain dibanding penjahit dengan penjahit dengan lama kerja $\leq 8$ jam.

Penelitian ini tidak sejalan dengan penelitian (Wahab, 2019) bahwa jam kerja 
per hari tidak berhubungan dengan kejadian nyeri punggung bawah pada nelayan.

\section{KESIMPULAN}

Berdasarkan penelitian tentang hubungan usia dan lama kerja dengan keluhan nyeri punggung bawah (low back pain) pada nelayan di Kelurahan Belawan II dapat ditarik kesimpulan:

1. Ada hubungan antara usia dengan keluhan nyeri punggung bawah (low back pain) pada nelayan di Kelurahan Belawan II dengan nilai $\mathrm{p}=0,004(\mathrm{p}<0,05)$

2. Ada hubungan antara lama kerja dengan keluhan nyeri punggung bawah (low back pain) pada nelayan di Kelurahan Belawan II dengan nilai $\mathrm{p}=0,032(\mathrm{p}<0,05)$

\section{UCAPAN TERIMAKASIH}

Peneliti mengucapkan terimakasih kepada pihak-pihak yang telah banyak memberi bantuan dalam proses penelitian sehingga artikel ini dapat terselesaikan.

\section{DAFTAR PUSTAKA}

Betty, P. (2020). Hubungan Lama Kerja dan Posisi Duduk Terhadap Kejadian Low Back Pain Pada Penjahit di Kota Pekanbaru. Jurnal Endurance, (Vol 5(2) Juni 2020). Retrieved from http://ejournal.lldikti10.id/index.php/ endurance/article/view/v5i24431/1795

European Agency for Safety and Health at Work. (2019). Musculoskeletal disorders. Retrieved from https://osha.europa.eu/en/themes/mus $\% 0$ Aculoskeletal-disorders

Kemenkes RI. (2018). Infodatin Keselamatan dan Kesehatan Kerja (K3). Kementerian Kesehatan RI.

Leni, A. S. M., \& Triyono, E. (2018). Perkembangan Usia Memberikan Gambaran Kekuatan Otot Punggung Pada Orang Dewasa Usia 40-60
Tahun. Gaster, 16(1), 5. Retrieved from https://jurnal.aiskauniversity.ac.id/index.php/gaster/artic le/view/237/164

Nurindasari. (2016). Gambaran Kejadian Low Back Pain Pada Pegawai Rektorat Uin Alauddin Makassar. Skripsi, 26-27.

PERMEN-KP. (2018). Jaminan Perlindungan Atas Risiko Kepada Nelayan, Pembudidayaan Ikan dan Pertambakan Garam. Retrieved from https://www.regulasip.id/book/3686/r ead

Ruhaya, F. (2018). Low Back Pain (LBP). Retrieved from http://www.yankes.kemkes.go.id/

Sangaji, M., Saalu, K., Sillehu, S., Umasugi, M. T., Hursepuny, J., Utami, T. N., \& Suparji. (2020). Musculoskeletal disorders complaints by part body fishermen village labuang namrole South Buru District. Indian Journal of Forensic Medicine and Toxicology, 14(2), 2598-2602. http://doi.org/10.37506/ijfmt.v14i2.35 10

Saputra, A. (2020). Sikap Kerja, Masa Kerja, dan Usia terhadap Keluhan Low Back Pain pada Pengrajin Batik. Higeia Journal of Public Health Research and Development, 1(3), 8494.

Tanderi, E., Kusuma, T., \& Hendrianingtyas, M. (2017). Hubungan Kemampuan Fungsional Dan Derajat Nyeri Pada Pasien Low Back Pain Mekanik Di Instalasi Rehabilitasi Medik Rsup Dr. Kariadi Semarang. Jurnal Kedokteran Diponegoro, 6(1), 63-72. Retrieved from

file://C:/Users/User/Downloads/1623 6-33054-1-SM.pdf

Utami, N. W. (2017). Hubungan Antara Masa Kerja Dengan Tingkat Keparahan Nyeri Punggung Bawah Pada Buruh Panggul Di Pelabuhan Tanjung Perak Surabaya. Universitas Hang Tuah Surabaya. Retrieved from 
https://repository.hangtuah.ac.id/inde x.php?p=show_detail\&id=1147\&key words $=$

Wahab, A. (2019). Faktor-Faktor Yang Berhubungan Dengan Keluhan Nyeri Punggung Bawah (Low Back Pain) Pada Nelayan Di Desa Batu Karas Kecamatan Cijulang Pangandaran. Biomedika, 11(1), 35. http://doi.org/10.23917/biomedika.v1 1 i1 1.7599

Waworuntu, Z., Kawatu, P. A. T., Akili, R. H., Kesehatan, F., Universitas, M., \& Ratulangi, S. (2019). Gambaran Keluhan Nyeri Punggnung Pada Pengendara Ojek Online Di Kota Manado. Kesmas, 7(5). Retrieved from

https://ejournal.unsrat.ac.id/index.php /kesmas/article/view/22422/22118 